\title{
PENGARUH PEMBERIAN SELAI KACANG TANAH DENGAN SUBSTITUSI BEKATUL MERAH TERHADAP KADAR GLUKOSA DARAH TIKUS DIABETES
}

\author{
Verhoeven Chelzea, Yekti Wirawanni*) \\ Program Studi Ilmu Gizi Fakultas Kedokteran Universitas Diponegoro \\ Jl.Dr.Sutomo No.18, Semarang, Telp (024) 8453708, Email : gizifk@ undip.ac.id
}

\begin{abstract}
ABSTRAK
Background: Diabetes mellitus is the third main causes of death in the world. High diet of fiber and antioxidant could be a choice/way to decrease the risks of diabetes mellitus. Fiber and antioxidant were highly found in peanuts and red rice bran. The objective of this study was to determine the effect of peanut butter with substitution of red rice bran on blood glucose level of diabetic rats.

Method : This study was a true experimental study with randomized pre-test and post-test control group design. Twelve male Wistar rats (2-3 months old, $\pm 200 \mathrm{~g})$ were induced by $120 \mathrm{mg} / \mathrm{kg}$ weight of alloxan to obtain the diabetic condition. Then, samples were divided into control group and treatment group. The control group was given $20 \mathrm{~g}$ of BR2. The treatment group was given $10 \mathrm{~g}$ of peanut butter with substitution of red rice bran and $10 \mathrm{~g}$ of BR2. Those interventions were done for 14 days. Normality test used Saphiro-Wilk method and the statistical analysis was done by using independent t-test and paired t-test.

Result : Blood glucose level in treatment group significantly decreased ( $p=0.004)$. The decrease of blood glucose level in treatment group was $29.17 \pm 14.30 \mathrm{mg} / \mathrm{dl}$, whereas in the control group was $2.17 \pm 5.15 \mathrm{mg} / \mathrm{dl}$. Statistical analysis showed that there was a significant difference of blood glucose level between the treatment group and the control group $(p=0.001)$.

Conclusion: Peanut butter with substitution of red rice bran in dosage 10 grams can significantly decrease the blood glucose level of diabetic male Wistar rats.
\end{abstract}

Key words : Peanut butter, rice red bran, blood glucose and diabetic male Wistar rats.

\section{ABSTRAK}

Latar Belakang: Diabetes mellitus menjadi penyakit mematikan nomer 3 di dunia menurut WHO. Salah satu cara menanggulangi yaitu dengan terapi diet (diet tinggi serat dan antioksidan). Beberapa bahan makanan dengan tinggi serat dan antioksidan ialah kacang tanah dan bekatul merah. Penelitian ini bertujuan membuktikan pengaruh selai kacang tanah dengan substitusi bekatul merah terhadap kadar glukosa darah pada tikus diabetes.

Metode : Penelitian ini merupakan penelitian true experimental dengan rancangan pre-post test randomized control group design dan termasuk dalam ruang lingkup gizi biomedik. Sampel sebanyak 12 ekor tikus putih jantan strain Wistar, berusia 2-3 bulan, berat badan $\pm 200 \mathrm{gr}$, sehat, lincah, dan mengalami diabetes. Sampel dibagi menjadi 2 kelompok, yaitu kelompok kontrol dan perlakuan. Seluruh tikus diinduksi aloksan secara intraperitoneal dengan dosis Aloksan $120 \mathrm{mg} / \mathrm{kg}$ BB yang diberikan sebanyak 1 kali. Kelompok perlakuan diberikan selai kacang tanah substitusi bekatul merah 10 gram secara sonde dan 10 gram BR2 secara oral selama 14 hari. Uji normalitas menggunakan Shapiro-Wilk dan analisis statisitik menggunakan uji independent t-test dan paired t-test.

Hasil : Kelompok perlakuan mengalami penurunan kadar glukosa darah yang bermakna $(p=0,004)$ sebesar $29.17 \pm 14.30 \mathrm{mg} / \mathrm{dl}$, sedangkan pada kelompok kontrol mengalami penurunan sebesar $2.17 \pm 5.15 \mathrm{mg} / \mathrm{dl}$. Secara statistik terdapat perbedaan perubahan kadar glukosa darah antara kelompok perlakuan dan kelompok kontrol yang bermakna $(p=0.001)$.

Kesimpulan : Konsumsi 10 gram selai kacang tanah substitusi bekatul merah selama 14 hari dapat menurunkan kadar glukosa darah pada tikus jantan galur Wistar yang diabetes secara signifikan.

Kata Kunci : Selai kacang tanah, bekatul merah, glukosa darah dan tikus jantan Wistar diabetes.

\section{PENDAHULUAN}

Perubahan gaya hidup dan pola makan dari makanan yang berbasis karbohidrat menjadi makanan serba instant, tinggi lemak, banyak mengandung gula serta kurangnya aktivitas fisik dapat meningkatkan timbulnya penyakit degeneratif seperti jantung koroner, hipertensi dan juga diabetes mellitus tipe 2., ${ }^{1,2}$ Diabetes Mellitus (DM) tipe 2 (Non-Insulin Dependent Diabetes Mellitus, NIDDM) merupakan kelainan yang ditandai dengan terjadinya hiperglikemia dan gangguan metabolisme karbohidrat, lemak dan protein yang dihubungkan dengan defisiensi fungsi atau sekresi insulin. ${ }^{3}$ Penyakit DM tidak dapat disembuhkan, namun dapat dikontrol. Menurut World Health Organization (WHO), penyakit DM merupakan penyakit mematikan nomor 3 di dunia dan Indonesia merupakan negara tertinggi ke 4 pengidap penyakit DM. Gaya hidup menjadi salah satu faktor yang dapat meningkatkan resiko DM tipe 2 yaitu

${ }^{*}$ Penulis Penanggungjawab 
dengan perubahan kebiasaan makan dengan gizi tidak seimbang antara asupan energi, karbohidrat dan protein. ${ }^{3}$ Asupan makanan padat energi (tinggi lemak dan gula) dan rendah serat berhubungan dengan kenaikan kadar glukosa darah. ${ }^{5}$

Salah satu upaya untuk menangani dan menanggulangi penyakit DM tipe 2 dengan perbaikan pola makan melalui pemilihan makanan yang tepat yaitu dengan diberikan terapi diet berupa memberikan makanan yang dapat menekan peningkatan kadar glukosa darah penderita yaitu diet tinggi serat dan tinggi antioksidan. ${ }^{1}$ Diet tinggi serat diperlukan untuk mengkontrol kadar glukosa darah yang dapat memperlambat penyerapan glukosa dengan memperlambat pengosongan lambung dan memperpendek waktu transit di usus. ${ }^{1}$ Diet tinggi antioksidan diperlukan untuk mencegah terjadinya hiperglikemia karena adanya autooksidasi glukosa yang dapat mempercepat pembentukan radikal bebas dengan cara mendonorkan atau memberikan elektronnya agar dapat menghambat aktivitas senyawa oksidan tersebut. $^{3}$

Serat dan antioksidan dapat ditemukan pada beberapa bahan makanan, contohnya terdapat pada kacang tanah dan bekatul merah. Kacang tanah (Arachis hypogeae L.) dilihat dari kandungan gizinya, memiliki nilai gizi yang tinggi. Terkandung 2 gram serat pangan, 3 miligram vitamin $\mathrm{C}$ dan 7,8 miligram vitamin $\mathrm{E}$ (alpha-tocopherol) dalam 100 gram kacang tanah. ${ }^{6}$ Peneliti Havard membuktikan, makan kacang tanah sebanyak 5 kali dalam seminggu secara teratur dalam jumlah \pm 30 gram dapat membantu mengendalikan kadar glukosa darah dan kadar insulin. ${ }^{7}$ Bekatul merah juga merupakan sumber serat dan antioksidan yang berguna bagi tubuh. Terkandung serat kasar $8,8 \%$ dan $58,69 \%$ antioksidan pada 100 gram bekatul merah. ${ }^{8}$ Penelitian mengenai bekatul merah membuktikan bahwa dalam waktu 2 minggu sebanyak 10 gram tepung bekatul dikonsumsi setiap hari oleh tikus putih jantan starin Wistar dapat menurunkan kadar glukosa darah sebesar 48,2\%. ${ }^{2}$

Banyaknya produk olahan kacang tanah yang ada, selai kacang tanah (peanut butter) merupakan salah satu produk yang banyak diminati oleh masyarakat. Selai kacang tanah dapat disubstitusikan dengan bekatul merah agar meningkat nilai gizinya. Hasil dari penelitian yang dilakukan sebelumnya selai dibuat dengan bahan dasar kacang tanah, susu cair, gula dan garam yang kemudian disubstitusikan dengan bekatul beras merah mempengaruhi kandungan gizi pada selai yaitu meningkatkan kandungan antioksidan, meningkatkan kandungan serat kasar dan menurunkan kadar glukosa darah. ${ }^{10}$ Berdasarkan penelitian, selai kacang tanah dengan substitusi bekatul merah dengan perbandingan 7:3 memiliki aktivitas antioksidan tertinggi yaitu sebesar 48,66\%. ${ }^{10}$ Selai kacang tanah dengan substitusi bekatul diharapkan dapat menjadi alternatif produk pangan untuk penderita diabetes. Berdasarkan pertimbangan dari penelitian dan uraian tersebut, peneliti ingin meneliti pengaruh pemberian selai kacang dengan substitusi bekatul merah terhadap kadar gula darah tikus diabetes.

\section{METODE PENELITIAN}

Penelitian dilakukan di Laboratorium Fisiologi Hewan Jurusan Biologi Fakultas MIPA Universitas Negeri Semarang pada bulan Juni 2015. Penelitian ini merupakan penelitian true experimental dengan rancangan pre-post test randomized control group design dan termasuk dalam ruang lingkup gizi biomedik. Sampel penelitian adalah tikus jantan wistar dengan kriteria inklusi berusia 2-3 bulan, berat badan tikus $\pm 200 \mathrm{gr}$, sehat, lincah, tidak kelainan dan tikus mengalami diabetes (glukosa darah saat puasa $>126 \mathrm{mg} / \mathrm{dl}$ ). Sampel dikeluarkan dari penelitian bila mati saat penelitian berlangsung, mengalami perubahan perilaku (menolak makan dan lemas) dan mengalami cacat atau kelainan.

Perhitungan sampel menurut penelitian hewan coba untuk perlakukan jangka pendek menggunakan peraturan dari $\mathrm{WHO}$, yaitu minimal 5 ekor. Untuk mengantisipasi drop out maka jumlah sampel menjadi 6 ekor untuk setiap kelompok. Sampel dibagi menjadi 2 kelompok yang terdiri atas kelompok kontrol dan kelompok perlakuan, masing-masing kelompok terdiri dari 6 sampel.

Sebanyak 12 tikus diaklamatisasi di Laboratorium MIPA Universitas Semarang selama 7 hari dengan menggunakan kandang individu. Suhu ruangan berkisar antara $28-32^{\circ} \mathrm{C}$ dengan siklus pencahayaan $12 \mathrm{jam}$. Tikus mendapat pakan standar yang diberikan secara oral sebanyak 20 gram per hari dengan air minum ad libitum selama 7 hari. Jenis pakan standar yang diberikan adalah standar BR 2 (Broiler Finisher) Comfeed dengan kandungan serat kasar maksimal 6\% dalam 100 gram. Hari ke 8 tikus diinduksi aloksan secara intraperitoneal dengan dosis Aloksan $120 \mathrm{mg} / \mathrm{kg} \mathrm{BB}$ yang diberikan sebanyak 1 kali dan pada hari ke 9 seluruh sampel diambil darahnya sebanyak $\pm 1 \mathrm{cc}$ untuk diperiksa kadar glukosa darah saat puasa sebelum intervensi.

Selai kacang dibuat secara masal untuk seluruh tikus dengan formula kacang tanah 87.5 gram, bekatul beras merah 37.5 gram, susu cair 500 
$\mathrm{ml}$, gula 50 gram dan garam 3 gram. Kacang tanah dikupas terlebih dahulu agar terbebas dari kotoran, kemudian kacang tanah disangrai pada suhu $\pm 80^{\circ} \mathrm{C}$ selama 10 menit lalu didinginkan agar proses pemanasan tidak berlanjut dan kadar minyaknya dapat dipertahankan. Kacang tanah yang telah disangrai kemudian diblender. Kacang tanah, bekatul merah dan susu dimasak pada suhu $\pm 80^{\circ} \mathrm{C}$ selama \pm 25 menit kemudian didinginkan. Tambahkan gula dan garam kemudian diaduk hingga rata. Adonan dimasak kembali hingga kalis ( \pm 15 menit), didinginkan lalu disimpan di wadah dan di masukan ke dalam lemari es.

Pemberian perlakuan pakan didapatkan dari kebutuhan pakan tikus sebesar $10 \%$ dari berat badan tikus, jika berat badan tikus rata-rata 200 gr maka jumlah kebutuhan pakannya ialah 20 gr. Kelompok perlakuan diberikan selai kacang dengan substitusi bekatul merah sebanyak 10 gram secara sonde dan 10 gram BR2 secara oral sedangkan kelompok kontrol mendapatkan pakan standar BR2 sebanyak
20 gram secara oral masing-masing selama 14 hari. Hari ke 23 seluruh sampel diambil darahnya kembali sebanyak \pm 1 cc untuk diperiksa kadar glukosa darah puasa setelah intervensi.

Pengolahan data dilakukan dengan menggunakan program komputer untuk analisis statistik. Data yang diperoleh merupakan hasil pemeriksaan kadar glukosa darah sampel seluruh kelompok. Data terlebih dahulu diuji normalitas menggunakan uji Saphiro-Wilk. Perbedaan kadar glukosa darah sebelum dan sesudah perlakuan diuji menggunakan uji paired t-test sedangkan untuk menguji perbedaan penurunan kadar glukosa darah pada kelompok kontrol dan kelompok perlakuan diuji menggunakan uji independent t-test.

\section{HASIL PENELITIAN \\ Karakteristik Sampel}

Karakteristik sampel yang terdiri dari berat badan, kadar glukosa darah sebelum perlakuan dan kadar glukosa darah sesudah perlakuan.

Tabel 1. Karakteristik Sampel

\begin{tabular}{|c|c|c|c|}
\hline \multirow[t]{2}{*}{ Karakteristik Sampel } & $\begin{array}{c}\text { Perlakuan } \\
(n=6)\end{array}$ & $\begin{array}{c}\begin{array}{c}\text { Kontrol } \\
(n=6)\end{array} \\
\end{array}$ & \multirow[t]{2}{*}{$\boldsymbol{P}$} \\
\hline & Mean \pm SD & Mean \pm SD & \\
\hline Berat Badan (kg) & $190.67 \pm 7.23$ & $193.83 \pm 7.83$ & 0.484 \\
\hline $\begin{array}{l}\text { Kadar Glukosa Darah Sebelum } \\
(\mathrm{mg} / \mathrm{dl})\end{array}$ & $146.17 \pm 11.72$ & $145.00 \pm 8.85$ & 0.850 \\
\hline $\begin{array}{l}\text { Kadar Glukosa Darah Sesudah } \\
\text { (mg/dl) }\end{array}$ & $117.00 \pm 15.63$ & $142.83 \pm 6.52$ & 0.004 \\
\hline
\end{tabular}

Uji Independent t-test

Sampel dalam penelitian merupakan tikus jantan galur wistar usia 2-3 bulan. Hasil uji beda terhadap berat badan baik kelompok perlakuan maupun kelompok kontrol menunjukan tidak ada perbedaan $(p=0.480)$. Rerata kadar glukosa darah sebelum perlakuan tidak menunjukan adanya perbedaan $(p=0.850)$, sedangkan rerata kadar glukosa darah sesudah perlakuan menunjukan adanya perbedaan yang bermakna $(p=0.004)$.

\section{Pengaruh Pemberian Selai Kacang Tanah Substitusi Bekatul Merah terhadap Kadar Glukosa Darah Tikus Diabetes \\ Pengaruh pemberian selai kacang tanah substitusi bekatul merah terhadap kadar glukosa darah tikus jantan galur wistar diabetes disajikan dalam tabel 2.}

Tabel 2. Pengaruh Pemberian Selai Kacang Tanah Substitusi Bekatul Merah terhadap Kadar Glukosa Darah Sebelum dan Sesudah Perlakuan

\begin{tabular}{|c|c|c|c|c|c|c|}
\hline \multirow[t]{2}{*}{ Kelompok } & $\begin{array}{c}\text { Kadar Glukosa } \\
\text { Darah Pre } \\
(\mathrm{mg} / \mathrm{dl})\end{array}$ & $\begin{array}{c}\text { Kadar Glukosa } \\
\text { Darah Post } \\
(\mathrm{mg} / \mathrm{dl})\end{array}$ & \multirow[t]{2}{*}{$p^{l}$} & \multicolumn{2}{|c|}{ Delta Penurunan } & \multirow[t]{2}{*}{$p^{2}$} \\
\hline & \multicolumn{2}{|c|}{ Mean \pm SD } & & Mean \pm SD & $\%$ & \\
\hline $\begin{array}{c}\text { Kontrol } \\
(n=6)\end{array}$ & $145.00 \pm 8.85$ & $142.83 \pm 6.52$ & 0.350 & $-2.17 \pm 5.15$ & 1.52 & \multirow[t]{2}{*}{0.001} \\
\hline $\begin{array}{c}\text { Perlakuan } \\
(n=6)\end{array}$ & $146.17 \pm 11.72$ & $117.00 \pm 15.63$ & 0.004 & $-29.17 \pm 14.30$ & 24.93 & \\
\hline
\end{tabular}

1. Uji Paired t-test

2. Uji Independent t-test 
Rerata kadar glukosa darah sebelum dan sesudah perlakuan diuji dengan menggunakan uji paired t-test. Rata-rata kadar glukosa darah tikus jantan galur Wistar pada kelompok kontrol sebelum perlakukan sebanyak $145.00 \pm 8.85 \mathrm{mg} / \mathrm{dl}$ dan setelah perlakuan sebanyak $142.83 \pm 6.52 \mathrm{mg} / \mathrm{dl}$. Hasil uji beda menunjukan tidak terdapat perbedaan yang bermakna dengan nilai $p=0.350$. Tikus jantan galur Wistar pada kelompok perlakuan memiliki rata-rata kadar glukosa darah sebelum perlakuan sebanyak $146.17 \pm 11.72 \mathrm{mg} / \mathrm{dl}$ dan setelah perlakuan sebanyak $117.00 \pm 15.63 \mathrm{mg} / \mathrm{dl}$. Hasil uji beda menunjukan perbedaan yang bermakna dengan nilai $p=0.004$.

Perbedaan rerata penurunan kadar glukosa darah antar kedua kelompok dianalisis dengan uji Independent $t$-test, terdapat perbedaan yang bermakna antara kelompok kontrol dan perlakuan $(p=0.001)$. Kelompok kontrol mengalami penurunan sebesar $2.17 \pm 5.15 \mathrm{mg} / \mathrm{dl} \quad(1.52 \%)$, sedangkan kelompok perlakuan mengalami penurunan sebesar $29.17 \pm 14.30 \mathrm{mg} / \mathrm{dl}(24.93 \%)$.

\section{PEMBAHASAN}

Kandungan serat dan antioksidan pada selai kacang tanah substitusi bekatul merah inilah yang mempengaruhi kadar glukosa darah pada kelompok perlakuan. Tinggi serat dan tinggi antioksidan pada selai kacang tanah dengan substitusi bekatul merah dapat menurunkan kadar glukosa darah pada kelompok perlakuan.

Pemberian serat pangan secara simultan di dalam jangka waktu lama mampu menurunkan tingkat glikemik serum, yaitu dengan memperlambat penyerapan glukosa melalui efek pengosongan lambung dan viskositas feses; serta menurunkan respons insulin. ${ }^{11}$ Serat pangan juga menghambat difusi glukosa serta akan menunda penyerapan dan pencernaan karbohidrat. ${ }^{12}$ Efek tersebut akan berdampak positif, keberadaan serat pangan dapat mengurangi laju penyerapan glukosa, sehingga tubuh tidak akan mengalami kelebihan glukosa. ${ }^{13}$ Serta diet yang mengandung banyak serat menyebabkan penundaan absorpsi bahan makanan di usus termasuk penundaan absorbsi karbohidrat, akibatnya kadar glukosa darah menurun. ${ }^{14}$

Mekanisme serat pada metabolisme gula darah berkaitan dengan fungsi dan karakteristik serat. Serat di dalam tubuh dapat menyerap cairan dan kemudian membentuk gel di dalam lambung. Gel inilah yang dapat memperlambat proses pengosongan lambung dan penyerapan zat gizi. Gel juga dapat memperlambat gerak peristaltik zat gizi (gula darah) dari dinding usus halus menuju daerah penyerapan sehingga terjadi penurunan kadar gula darah. ${ }^{15}$

Serat merupakan komponen yang tidak dapat dicerna dan diserap di dalam usus halus. Bagian serat yang tidak tercerna akan menuju ke dalam usus besar. Serat akan diubah menjadi substrat yang dapat difermentasikan oleh bakteri di dalam usus besar. Fermentasi serat oleh bakteri menghasilkan asam-asam lemak rantai pendek jenis asetat dan propionat. Asam-asam lemak tersebut akan diserap kembali menuju ke aliran darah. Asetat dapat menurunkan asam-asam lemak bebas di aliran darah dalam jangka waktu yang lama. Hal ini mempunyai efek baik bagi penurunan kadar gula darah dan sensitivitas insulin dalam jangka waktu lama karena asam-asam lemak bebas dapat menghambat proses utilasi gula darah di jaringan dan membantu menghambat resistensi insulin. ${ }^{15}$ Propionat dapat menghambat kerja HMG CoA reduktase, menghambat mobilisasi lemak dan mencegah proses glukoneogenesis di dalam hati. Selain itu, propionat juga menurunkan reduksi asam-asam lemak bebas di dalam darah yang dapat menghambat resistensi insulin dan mencegah proses utilasi gula darah oleh jaringan dalam jangka waktu lama. Kerja propionat tersebut dapat menyebabkan peningkatan sekresi insulin sehingga terjadi penurunan kadar gula darah. ${ }^{15}$

Antioksidan yang terkandung pada selai kacang substitusi bekatul merah ialah tocopherols, tocotrienols, gamma-oryzano. Penelitian di Swedia menunjukkan bahwa pemberian $\alpha$-tocopherol ternyata dapat mencegah diabetes dan melindungi gangguan ginjal pada tikus. Pemberian diet yang kaya tocotrienol juga dapat menurunkan kadar glukosa darah dibanding pada hewan uji kontrol. ${ }^{16}$ Antioksidan mempunyai kemampuan sebagai astrigen yaitu dapat mempresipitasikan protein selaput lendir usus dan membentuk suatu lapisan yang melindungi usus, sehingga menghambat asupan glukosa yang menyebabkan laju peningkatan glukosa darah tidak terlalu tinggi. ${ }^{16}$ Antioksidan juga mempercepat keluarnya glukosa dari sirkulasi dengan cara mempercepat peredaran darah yang erat kaitannya dengan kerja jantung dan dengan cara mempercepat filtrasi dan ekskresi ginjal sehingga produksi urin meningkat, laju eksresi glukosa melalui ginjal meningkat sehingga kadar glukosa dalam darah menurun. Serta dapat mempercepat keluarnya glukosa melalui peningkatan metabolisme atau memasukan ke dalam deposit lemak. Proses ini melibatkan pankreas untuk memproduksi insulin. ${ }^{16}$ 


\section{SIMPULAN}

Pemberian 10 gram selai kacang tanah substitusi bekatul merah selama 14 hari berpengaruh terhadap penurunan kadar glukosa darah pada tikus jantan galur Wistar yang diabetes.

\section{SARAN}

Berdasarkan hasil penelitian ini, maka dapat dilakukan pengembangan penelitian yang diaplikasikan ke manusia untuk menurunkan kadar glukosa darah saat puasa.

\section{DAFTAR PUSTAKA}

1. Marsono Y, Noor Z, and Rahmawati F. Pengaruh Diet Kacang Merah Terhadap Kadar Gula Darah Tikus Diabetik Induksi Alloxan. Jurnal Teknol dan Industri Pangan, Vol XIV No 1. 2003.

2. Bintanah S, Kusuma HS. Pengaruh Pemberian Bekatul dan Tepung Tempe Terhadap Profil Gula Darah Pada Tikus Yang Diberi Alloxan. Jurnal Pangan dan Gizi, Vol 01 No 02. 2010.

3. Nintami AL, Rustanti N. Kadar Serat, Aktivitas Antioksidan, Amilosa dan Uji Kesukaan Mi Basah dengan Subtitusi Tepung Ubi Jalar Ungu (Ipomoea Batatas Var Ayamurasaki) Bagi Penderita Diabetes Melitus Tipe 2. Journal of Nutrition College, Vol 1 No 1. 2012 : 382-387.

4. Perdana YAW, Sampurna, and Chodijah. Uji Efektivitas Air Rebusan Buncis (Phaselous Vulgaris Linn) dan Bekatul Terhadap Kadar Glukosa. Fakultas Kedokteran Universitas Islam Sultan Agung, Vol 2 No 1. 2010.

5. Fitri RI, Wirawanni Y. Asupan Energi, Karbohidrat, Serat, Beban Glikemik, Latihan Jasmani dan Kadar Gula Darah Pada Pasien Diabetes Millitus Tipe 2. Media Medika Indonesiana, Vol 46 No 2. 2012.

6. Astawan M. Sehat dengan Hidangan Kacang dan Biji-Bijian. Penebar Swadaya. Depok: 2009.

7. Ide P. Seri Diet Korektif Diet South Beach. Alex Media Komputindo. Jakarta: 2007.

8. Jayanata CE, and Kholil A. Gaya Hidup Organik. Healthy Life. Jakarta: 2013.

9. Mumpuni PD. Analisis Kadar Tokoferol, $\gamma$ Orizanol, $\beta$-Karoten serta Aktifitas Antioksidan Minyak Bekatul Kasar. Program Studi Ilmu Gizi Universitas Diponegoro. 2013.

10. Susanto D. Potensi Bekatul Sebagai Sumber Antioksidan dalam Produk Selai Kacang. Program Studi Ilmu Gizi Universitas Diponegoro. 2011.

11. Galisteo M, Duarte J, Zarzueloa A. Effects of dietary fibers on disturbances clustered in the metabolic syndrome. J Nutr Biochem. 2008;19(2):71-84.)

12. Galisteo M, Duarte J, Zarzueloa A. Effects of dietary fibers on disturbances clustered in the metabolic syndrome. J Nutr Biochem. 2008;19(2):71-84.
13. Hernawati, Manalu W, Suprayogi A, and Astuti DA. Perbaikan Parameter Lipid Darah Mencit Hiperkolesterolemia dengan Suplemen Pangan Bekatul. Institut Pertanian Bogor. 2013.

14. Nashriana N, Wirjatmad B, and Adriani M. Combine Food (Bekatul dan Lemak) Menurunkan Kadar Kolesterol Total, Trigliserida, dan LD Pada Tikus Galur Wistar. Universitas Brawijaya. 2015.

15. Witasari U, Rahmawaty S, Zulaekah S. Hubungan tingkat Pengetahuan, Asupan Karbohidrat dan Serat dengan Pengendalian Kadar Glukosa Darah pada Penderita Diabetes Melitus Tipe 2. Universitas Muhammadiyah. 2009.

16. Oliveira MDS, Cipolatti EP, Furlong EB, and Soares LDS. Phenolic Compounds and Antioxidant Activity in Fermented Rice (Oryza Sativa) Bran. Ciencia e Tecnologia de Alimentos. 2012. 